\title{
Processos de resistência na Amazônia nos tempos da Ditadura Civil-Militar: entre a memória e a história
}

\author{
Processes of resistance to dictatorship Civil -Military (1964- \\ 1985) in the Brazilian Amazon: between memory and history
}

\author{
Elias Diniz SACRAMENTO \\ Universidade Federal do Pará - Campus do Tocantins/Cametá
}

\begin{abstract}
RESUMO: Este artigo procura mostrar a memória de uma literatura que retrata a resistência de sujeitos de uma Amazônia que foi tomada nos meados dos anos de 1960 do ultimo século quando os militares com apoio de certa parcela da sociedade civil deram um golpe na democracia brasileira. Desde esse período, grandes mudanças e transformações ocorreram no seio destas sociedades que passaram a viver sob tensões por conta do modelo pensado para a região com a chegada e instalação de vários projetos de médios e grandes portes. Frente a isso, o que se viu nos anos seguintes foram momentos de grandes tensões, acima de tudo pelas forças do grande capital se fez presente em terras amazônicas nunca antes visto. As populações tradicionais, então resolveram fazer enfrentamentos a esse modelo devastador, naquilo que chamaremos aqui de resistência aos projetos militares. Tais ações dessas comunidades transformaram-se anos mais tarde em trabalhos de pesquisa que irei tratar aqui como literatura de resistência, procurando mostrar alguns desses casos, ou os mais emblemáticos, finalizando com um caso especial, o do município de Moju.
\end{abstract}

PALAVRAS-CHAVE: Resistência; Amazônia; Ditadura Civil-Militar.

ABSTRACT: This article aims to show the memory of a literature that portrays the subject of resistance of an Amazon who was taken in the mid-1960s of the last century when the military to support a certain portion of the civil society staged a coup in Brazilian democracy. Since that time, major changes and transformations occurred within these societies that were living under stress because of the thought model for the region with the arrival and installation of various medium and large sized projects. Faced with this, what we saw in the years were moments of great tensions, above all by the forces of big capital was present in Amazonian lands never seen before. Traditional populations, then decided to make fighting this devastating model, what we call here of resistance to military projects. Such actions of these communities have become years later in search of jobs that will treat here as resistance literature, trying to show some of these cases, and the most emblematic, ending with a special case, the city of Moju.

KEYWORDS: Resistance; Amazon; Civil-military dictatorship.

\section{Introdução}

No ano de 2014, quando o Golpe Civil-militar no Brasil completou cinquenta anos, travou-se grande debate acerca do tema em questão. Vários eventos acadêmicos voltados para públicos diversos ocorreram. Lançamentos de publicações como livros, artigos, apresentação de trabalhos em Simpósios Temáticos. Depoimentos de vitimas do período do regime ditatorial foram apresentados e ganharam visibilidade. Um pouco 
antes, Comissões da Verdade foram criadas em praticamente todo o território Brasileiro. A Comissão Nacional da Verdade $^{1}$, criada pelo Ministério da justiça, sob a coordenação da Comissão da Anistia foi a mais importante. Porém, outras também tiveram destaques no Cenário Nacional, como a Comissão Camponesa da Verdade, ligada a Comissão Pastoral da Terra (CPT) entidade da Comissão Nacional dos Bispos do Brasil (CNBB).

De caráter mais regional, no estado do Pará foram criadas as seguintes comissões: Comissão Estadual da Verdade do Pará ${ }^{2}$, entidade ligada à Ordem dos Advogados do Brasil (OAB-PA), Assembleia Legislativa do Estado do Para (ALEPA), Sociedade de Defesa dos Direitos Humanos (SDDH-PA), além de outros segmentos sociais que integraram esta Comissão. A Universidade Federal do Para (UFPA) não ficou de fora deste processo e também criou sua comissão, a Comissão Cezar Leite de Moraes ${ }^{3}$.

Esta comissão tinha como proposta verificar casos de perseguições, torturas, prisões de professores, funcionários, alunos no período ditatorial e ate mortes, como foi o caso do jovem estudante de Matemática Cezar Leite de Moraes, ocorrido no dia 10 de março de 1980 na sala 02, do bloco F, no Campus Básico da UFPA. Para tanto, foram escolhidos membros para fazerem parte desta comissão, sendo composta por professores, técnicos e alunos que tiveram como finalidade verificar documentações, ouvir depoimentos dos que sofreram algum tipo de perseguição ou tortura no período citado. Diversos casos foram relatados e de forma emocionada, depoimentos foram coletados e alimentaram uma de dados sobre a ditadura, guardado no Repositório da UFPA.

Todas essas ações referentes ao tema da Ditadura Civil-Militar tinham como meta não deixar passar em branco a data, uma vez que ao completar cinquenta anos, havia uma lembrança muito recente e marcante da memoria deixada pela dor e pelo sentimento de justiça que não aconteceu no caso brasileiro, pois os militares, ou seus

\footnotetext{
${ }^{1}$ A Comissão Nacional da Verdade foi criada pela Lei 12528/2011 e instituída em 16 de maio de 2012. A CNV tem por finalidade apurar graves violações de Direitos Humanos ocorridas entre 18 de setembro de 1946 e 5 de outubro de 1988.

${ }^{2}$ Através da Organização do Comitê Paraense pela Verdade, Memória e Justiça, criado em 24 de agosto de 2011, a criação da Comissão já estava sendo discutida. No dia 19 de março deste ano, a Assembleia Legislativa aprovou o projeto de lei $\mathrm{n}^{\circ}$ 62/2014.

${ }^{3}$ Resolução N. 721, DE 20 de setembro de 2013. Cria a Comissão "César Leite" de Memória e Verdade da Universidade Federal do Pará.
} 
colabores, nada sofreram após o retorno da democratização. A lei de Anistia, ampla, geral e irrestrita não teve como penalizar ninguém.

Os cinquenta anos do golpe foram um acontecimento significativo, uma vez que possibilitou uma dinâmica de organizações de entidades, movimentos sociais para cobrar por memória e justiça, principalmente dos torturadores, na perspectiva que pudessem pagar por seus crimes de violações dos direitos humanos no Brasil. Também representou um momento em que foi os sujeitos afetados ou suas famílias puderam cobrar pelas reparações com indenizações, com base na Lei de Anistia. Outro fator de grande importância foi a publicação de uma vasta literatura sobre o tema.

Não representou um momento de comemoração, celebração, mas sim de produzirem grandes reflexões sobre a temática e a diversidade de literatura foi significativa, com contribuições de varias áreas do conhecimento cientifico. Livros, capítulos de livros, artigos e outros textos foram apresentados no Brasil e em âmbito internacional afora, em diferentes áreas: sociologia, psicologia, Letras, história, antropologia, educação.

Nesse sentido, trabalhos como de Jorge Ferreira e Ângela de Castro Gomes “1964: o golpe que derrubou um presidente pôs fim ao regime democrático e instituiu a ditadura no Brasil", Mário Sérgio de Moraes "50 anos construindo a democracia: do golpe de 64 a Comissão Nacional da Verdade", Daniel Aarão Reis "Ditadura e democracia no Brasil: do golpe de 1964 à Constituição de 1988”, são alguns exemplos de autores que produziram literaturas pensando no tema, e obviamente procurando mostrar as histórias de resistências no Brasil no referido período.

Toda essa literatura teve uma grande importância, uma vez que além de trazer uma memória coletiva, às vezes adormecida por certo período, também servirá para gerações futuras compreenderem o processo que ocorreu em um certo momento da historia do Brasil, e que tem-se a necessidade de se buscar esclarecimentos a cerca da questão, principalmente para que nunca mais aconteça, para que nunca mais se repita.

As contribuições do ano de 2014 de trabalhos apresentados pelo Brasil tiveram significativa influência na Amazônia, mais particularmente no estado do Pará e na Universidade Federal do Para também. Este momento suscitou possibilidades de novas pesquisas pensando no tema, como também visibilizou a literatura acadêmica já produzida na região, com debates relacionados à questão de resistências, principalmente 
pelas chamadas lutas de classe, conceito utilizado por Karl Marx e que ainda hoje possui grande forca no meio de produção do trabalho.

Neste artigo, consideramos a importância dos trabalhos produzidos no bojo do cinquentenário da Ditadura Civil-Militar no Brasil e na Amazônia, mas vamos nos deter em analisar alguns trabalhos produzidos nas décadas anteriores sobre o enfrentamento junto aos projetos dos militares que se instalaram na região amazônica. Cabe dar destaque a algumas dessas literaturas para chegarmos a uma noção mais clara sobre o regime dos militares com apoio de uma parte da sociedade civil no poder, o que fizeram e o que restou pós-regime.

\section{Conflitos e resistência na Amazônia}

A resistência a processos autoritários na Amazônia não é uma realidade recente. Desde a chegada dos colonizadores no século XVII, mais precisamente por volta do ano de 1616, quando Francisco Caldeira Castelo Branco aportou nas terras do norte do Brasil, no intuito de expulsar franceses e ingleses que comercializavam com povos nativos da região, já se tem noticias dos primeiros conflitos e de formas de resistência. Expulsos então os inimigos dos portugueses de outras bandeiras de nacionalidade europeia, restou aos índios conhecidos como Tupinambás o papel de enfrentamento contra os lusitanos.

De acordo com produções historiográficas, foram dias de tensões e combates até que os indígenas fossem tidos como vencidos. Um dos mais conhecidos líder dessa resistência foi o indígena Guaimiaba, conhecido também por Cabelo de Velha, referência aos seus longos cabelos embranquecidos. Guaimiaba passou a fazer parte da 'historia dos vencidos', na região. Trata-se, portanto, de um dos primeiros líderes da resistência local, e sua atuação é fundamental para que as histórias desta região não fossem contadas por uma única versão.

Durante os séculos e colonização na Amazônia, outros personagens desafiaram as ordens superiores. Um dos casos mais emblemáticos da literatura recente, do início do século XIX está relacionado aos momentos mais tensos vivenciados pela Cabanagem no ano de 1835, quando homens pobres da Província do Grão Pará, como índios, escravos, tapuios fizeram o maior levante da historia do Brasil, depondo o presidente provincial da época conhecido por Lobo de Souza. Neste episodio, o então presidente 
não foi apenas retirado do seu cargo de chefe maior, mas foi morto pelo cabano Domingos Onça com um tiro certeiro no peito, nas escadas da sede do governo, hoje conhecido como Palácio Lauro Sodré (RICCI, 2006).

Outro caso especifico ocorrido na década de 1930, mais precisamente em 1932, durante a Revolução Paulista, uma guerra civil causada pelas insatisfações de setores sociais contra a politica de Getúlio Vargas, também vai repercutir na Amazônia. No estado do Para, mais precisamente na cidade de Óbidos, ocorreu um levante de apoio ao movimento de São Paulo. De forma impressionante, os ecos soaram por essas bandas nortistas, em uma cidade localizada a muitos quilômetros de Belém, na região oeste do Pará.

Este acontecimento está descrito em "1932 - A Revolução Constitucionalista no Baixo Amazonas: contexto, revolta e produção do silêncio" (2013), de Walter Pinto de Oliveira, que narra alguns dos episódios mais marcantes desse momento de um conflito na região sudeste do Brasil e mostra como grupos de homens comuns de uma parte da Amazônia tiveram um papel importante nesta revolta. Obviamente, que os 'rebeldes', tanto de São Paulo quanto os daqui foram sufocados, derrotados, vencidos. Mas o mais significativo desse processo é que não se calaram, não se omitiram, ou seja, fizeram parte da historia, fizeram historia.

\subsection{Resistência na Amazônia em tempos da ditadura}

Este trabalho tem como objeto principal falar sobre algumas literaturas produzidas no campo da historiografia da Amazônia que estejam relacionadas às diversas resistências, ou modos de resistência em vários espaços. Estes processos de resistências, primeiro se formam no campo social, da luta travada entre sujeitos, grupos de homens e mulheres habitantes de um determinado lugar, que em certo momento sofreram tentativas de serem retirados de seus lugares. Esse contexto foi muito comum após o golpe militar no Brasil após o ano de 1966, quando as fronteiras da Amazônia foram abertas para o capital nacional e internacional e culminaram com a chegada de vários projetos agroindustriais, minerais que se instalaram nesta região.

A Amazônia, em quase todo o seu século XX, pós-decadência do boom da borracha, se encontrava movida por uma economia estável. Com o declínio da hevea brasiliense, a região sofreu uma diminuição significativa no modelo econômico que 
estava se implementando nos tempos áureos da borracha. A Amazônia não parou, mas diminuiu bastante o ritmo de atividades econômicas, até a chegada dos militares ao poder, nos anos de 1960, quando os olhares se voltaram para a região novamente.

Essa nova investida foi muito diferente dos anos da belle époque, quando a influência dos governantes daquela época, primeiro do Imperador Dom Pedro II e dos presidentes da Republica não propunha a derrubada da floresta, mas sim incentivos para a vinda de homens que pudessem tirar o látex da seringueira. Neste período, a floresta tinha mais valor com suas árvores nativas produzindo.

Com o regime militar, a posição foi diferente e o incentivo dado ao capital nacional e internacional era para que a floresta pudesse ser desmatada. As árvores deveriam ser transformadas em madeira, desta forma abrindo espaços para criação de gado bovino, produção de carvão, implantação de grandes projetos de soja, eucalipto, pinho, dendê, coco, além da construção de hidrelétricas, siderúrgicas, áreas portuárias entre outros grandes investimentos.

\subsubsection{A expansão da pecuária: Gleba Cidapar}

Todos esses projetos foram inevitáveis nos períodos que se seguiram aos governos militares, principalmente no estado do Pará, que foi fatiado e seu território dividido para a exploração de projetos. Assim, a região nordeste do Pará, por exemplo, mais próxima da rodovia BR-316 sofreu uma grande influencia com ideais para a criação de gado. Foi nessa região que ocorreu o famoso caso da disputa da terra por posseiros de vários municípios como Viseu, Capitão Poço, Irituia, Garrafão do Norte com diversas empresas. Tal disputa ficou conhecida como conflito da Gleba Cidapar.

Violeta Loureiro descreveu esse conflito no livro Estado, bandidos e heróis: utopia e luta na Amazônia (1996). Este episódio ficou marcado também pelo surgimento de um personagem emblemático neste cenário, o gatilheiro Quintino, Armando Lira, 'matador de cabra safado', uma espécie de Robin Hood amazônico, um Lampião do Norte, na memória dos camponeses da região descritos pela autora. Mas também, um perigo para os donos dos negócios da região, um fora da lei, um bandido. Por isso o titulo da obra de Loureiro, as varias formas de ver o sujeito. Na luta pela terra nesta região, houve varias formas de resistência, entre elas, a do enfrentamento, e algumas delas à bala. O final, para Quintino, foi trágico, morto pela policia do Estado 
do Pará, do então governador Jader Barbalho, as vésperas da inauguração do monumento da Cabanagem na entrada da cidade de Belém, obra que foi encomendada ao então renomado arquiteto de Brasília, Oscar Niemayer, foi ofuscado.

\subsubsection{Sobre a exploração mineral no estado do Pará}

Na região oeste do estado do Pará, por exemplo, projetos dos militares incentivaram a exploração de bauxita no município de Oriximiná e ali se instalou a Mineradora Rio do Norte, onde entrou em conflitos com várias comunidade quilombolas do vale do Trombetas. Comunidade remanescentes de quilombos sofreram grandes impactos provocados pelos resíduos dos minérios despejados nos rios próximos dessas comunidades. O exemplo mais claro do problema foi detectado no chamado lago Batata, que sofreu grande poluição ficando as populações proibidas de utilizarem a água e os peixes desse rio.

O caso das comunidades quilombolas de Oriximiná foi descrito pelas antropólogas Rosa Acevedo e Edna Castro em Negros do Trombetas: guardiães de matas e rios (1998), onde destacam a resistência das comunidades remanescentes de quilombos, principalmente comunidades que viviam em situações criticas, como Boa Vista e Cacheira Porteira. Nessas duas comunidades, impactadas pelos empreendimentos da Mineradora Rio do Norte, as famílias vivem cercadas pelas águas em seus territórios, sem poderem utilizar este recurso, como faziam os antigos moradores. Grande parte desse território passou a fazer parte, desde os anos de 1970 da empresa responsável pela retirada da mineração, localizada no entorno dessas comunidades.

Em Barcarena, por exemplo, quando da instalação da empresa Albrás/Alunorte grandes transformações se deram nesta região, considerada como micro região Guajarina. (MAIA; MOURA: 1995). Famílias que viviam basicamente da extração de atividades de agriculturas de subsistência, bem como da caça e da pesca, do extrativismo, foram levadas a se fixarem na empresa. Grande parte delas teve que mudar seus modos de vida, de produção, deixando de serem livres, para serem assalariados.

Ainda sobre a empresa Albrás/Alunorte, Edilza Fontes (2003) retrata os conflitos

estabelecidos dentro da indústria no Porto de Barcarena. A pesquisadora discute a 
problemática relacionada ao modo de exploração de trabalho nos anos iniciais de operação da empresa, quando não eram claras as legislações de trabalho para os operários. A autora destaca que os mais prejudicados eram os 'peões da casa', chamados de cabaço pelos 'peões do trecho', uma vez que estes ainda eram muito ingênuos, puros, enquanto os peões do trecho eram rodados, já vinham de outras obras, de outras construções. Sua sina era a de seguir o fluxo das grandes construções de empreendimentos Brasil a fora. O peão da casa então sofria nesse contexto, até pegar o jeito da coisa.

Questões complexas foram vivenciadas em grande intensidade nas regiões sul e sudeste do Pará. Grandes projetos de mineradoras, hidrelétricas, criação de gado se estabeleceram nessas regiões com o aval dos governos militares e sem nenhum pudor transforaram a região num verdadeiro campo de batalha. Expropriação de terras devolutas, terras comunidades tradicionais como quilombolas, indígenas e de moradores que habitavam a área há muito tempo foram tomadas. $\mathrm{O}$ número de trabalhadores mortos nessa região é quase incontável. Na verdade, não se tem dados corretos de forma oficial, embora Comissão Pastoral da Terra (CPT) tente fazer isso.

\subsubsection{Assassinato no campo: os números imprecisos}

No livro Retrato da Repressão Política no Campo - Brasil de 1962 a 1985: Camponeses torturados, mortos e desaparecidos (2011), organizado pelo Ministério do Desenvolvimento Agrário do governo federal traz um amplo debate sobre os mais diversos tipos de crimes praticados pelos militares, nos mais diversos espaços do rural brasileiro. No estado do Pará, o livro traz um número total de 74 nomes de pessoas que foram assassinadas no campo, sendo estes crimes cometidos das mais diversas formas. Há um destaque para três personagens: Raimundo Ferreira Lima, o Gringo, Expedito Ribeiro e Padre Jósimo Morais Tavares. Os dois primeiros, lideranças sindicais assassinados, o segundo, inclusive foi morto em 1991, mas ainda sob a consideração da responsabilidade dos governos militares (CARNEIRO; CIOCCARI, 2011, p. 265; 269; 273).

Outras produções destacam o grande número de trabalhadores assassinados no campo amazônico no período ditatorial, principalmente o paraense. Barata (1995) descreve assassinatos que ocorreram no estado do Pará dos anos de 1980 a 1989. Foram 
centenas de casos, vitimando lideranças sindicais, padres, advogados, freiras, políticos, pistoleiros, fazendeiros, grileiros de terras entre outros. Embora o livro seja baseado nas matérias de jornais, fica claro que o número de assassinatos no campo amazônico é bastante expressivo, principalmente no estado do Pará. O livro mostra os números e em nenhum momento o autor defende que os casos registrados em seu livro tenham algo a ver com o projeto dos militares para a Amazônia.

Em um livro recente “A militarização da Amazônia de 1964 a 1965”, apresentado por Schmink e Wood (2012) apresentam o ideal dos governos militares para a região amazônica. As diversas políticas de desenvolvimento, quase sempre agressivas tinham como objetivos atrair investimentos para a região.

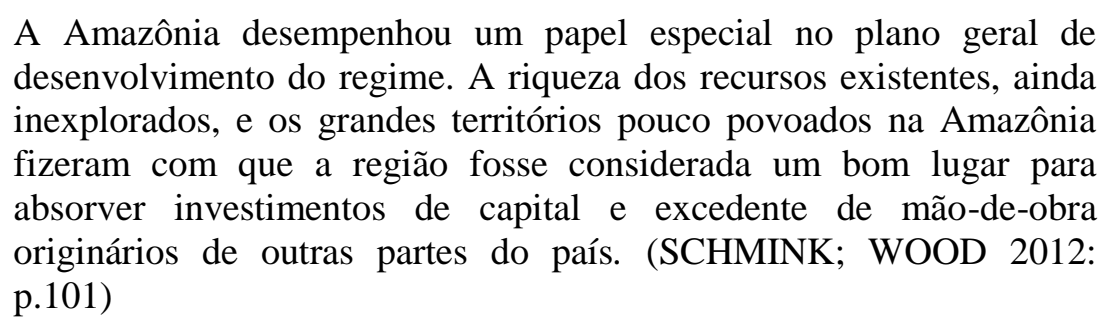

Continuam os autores, frisando que outra meta dos militares era o controle das terras na Amazônia. Até então as estruturas dominantes eram da jurisdição de estados e municípios, em um modelo arcaico de manutenção do poder local. Os militares, logo após o golpe passaram esse controle para a esfera federal. No entanto, esse modelo de gestão só fez piorar a situação, quando se iniciou um grande numero de violência no campo, fato que os órgãos criados não deram conta de resolver (SCHMINK; WOOD, 2012, p. 128).

Para Petit (2003), as transformações ocorridas no período da ditadura militar no Pará foram muito intensas, mas também havia um histórico de uma elite que estava no poder há décadas. O autor destaca também os 'discursos regionalistas', uma vez que segundo estes alguns homens do setor das indústrias eram favoráveis à intervenção e outros contrários.

Como se pode ver, as contradições foram diversas em relação aos projetos para a Amazônia, resultando nos mais diversos conflitos. Conflitos de interesses de uma elite local, conflitos entre populações tradicionais, como povos indígenas, quilombolas, camponeses, e entre essas populações tradicionais e os imigrantes que vieram em busca de terras ou simplesmente de pegar os recursos destinados pelos governantes. Todos 
esses conflitos provocaram danos sérios, como as torturas muitas vezes, desaparecimentos, e as mortes por assassinatos. As marcas ficaram em varias partes da Amazônia, mas principalmente no estado do Pará, principalmente nas regiões do sul, oeste e nordeste do estado.

Em Rio Maria, município localizado no sul do Pará, por exemplo, os rastros da violência causada pelo projeto dos militares deixaram vários mortos, entre eles, uma família quase toda, pai e dois filhos. João Canuto, o pai e José e Paulo Canuto, os filhos. Outro assassinato bárbaro foi do também sindicalista Expedito Ribeiro, no mesmo município. Em toda a região do sul do Pará, centenas de mortes são contadas depois da tomada dos governos militares. No caso de Rio Maria, os conflitos intensos que culminaram com todas essas mortes estiveram ligadas ao empreendimento da agropecuária, da criação extensiva de gado, onde trabalhadores rurais ligados à pequena produção não poderiam permanecer. (FIGUEIRA, 1993).

Outro acontecimento conhecido nacionalmente e internacionalmente foi $o$ Massacre de Eldorado dos Carajás, ocorrido no ano de 1996, quando mais de 19 trabalhadores sem-terra foram mortos pela policia, no episódio também conhecido como curva do 'S'. Sendo mais um caso interpretado como além da responsabilidade dos governos militares. A morte desses 19 trabalhadores foi decorrente da morosidade dos governos em desapropriar áreas que haviam sido concedidas no período dos governos militares, e que já nos anos de 1990 encontravam-se improdutivas, não sendo utilizados nem sequer para pastagem. Nesse contexto, formaram-se vários acampamentos nestas áreas, pressionando os governantes a desapropriarem-nas.

No dia 17 de abril de 1996, havia nas proximidades do município de Eldorado dos Carajás um grande contingente de homens e mulheres que estavam em uma marcha rumo a Belém, para pressionar o governo do Estado, então Almir Gabriel a agilizar esses processos de desapropriação dessas áreas. O governador havia se comprometido na manhã desse dia, em mandar dois ônibus e mantimentos para os acampados. No entanto, no final da tarde, o que chegou foram ônibus sem os mantimentos, apenas com tropas militares das cidades de Parauapebas e Marabá. Na sequencia, aconteceu o massacre dos 19 trabalhadores sem terra. (BRELAZ, 2006).

\section{2. “Quem atirou”? “Quem estava armado”? União e resistência em Moju}


As almas da terra: a violência no campo mojuense (SACRAMENTO, 2012) apresenta alguns trechos que resumem a história da luta pela terra no município de Moju. Retrata a chegada de vários projetos agroindustriais e consequentemente a resistência dos trabalhadores, quando em diferentes ocasiões foram para o enfrentamento. É uma obra que procura mostrar o espaço do município de Moju, localizado na região nordeste do estado do Pará, na microrregião Guajarina, da qual fazem parte Abaetetuba, Barcarena, Acará, Concorrida do Pará, Bujaru, Tailândia, Tomé-Açú e o próprio Moju.

O município de Moju é um dos mais antigos do Pará, fundado antes da independência do Brasil, no tempo em que a região fazia parte da Província do GrãoPará. O primeiro nome desta povoação, em 1835, foi freguesia do Divino Espirito Santo, numa doação de terras realizada pelo senhor Francisco Dorneles. A sede do município está situada na margem direita do rio do mesmo nome, em terrenos doados pelo Capitão-Mor Antônio Dorneles de Souza à Irmandade do Divino Espírito Santo, em julho de 1754, quando o Bispo D. Frei de Bulhões, em visita pastoral hospedou-se no sítio deste cidadão. Segundo Batista (2013, p. 89):

\footnotetext{
A freguesia de Moju originou-se de um povoado fundado nas terras de Antônio Dornelles de Sousa, o qual tinha recebido de herança de seu pai, o padre Gusmão localizadas dentro da área patrimonial da freguesia de Igarapé-Miri. Após ter sido doado à Irmandade do Divino Espírito Santo, recebeu invocação do santo da irmandade. Em julho de 1754, por ocasião da visita feita ao lugar pelo Bispo do Pará, Frei Miguel de Bulhões, o povoado foi elevado à categoria de freguesia.
}

O município limita-se ao Norte com os Municípios de Abaetetuba e Barcarena; a Leste com os municípios de Acará e Tailândia; ao Sul com o município de Breu Branco e, a Oeste com os Municípios de Baião, Mocajuba e Igarapé-Miri. Em fins dos anos de 1970, diversos projetos agroindustriais chegariam ao município. Os primeiros projetos a se fixarem foram os de produção de dendê, localizados na recém-criada Rodovia PA- 150, que passou a ligar o município de Moju ao sul do Pará e a produção de coco no entorno da antiga Rodovia PA- 252, que ligava Moju ao município de Acará, além de uma extensa área de criação de gado em várias partes deste município. Já no inicio dos anos de 1980, na região de Jambuaçú, localizada no baixo e médio Moju, onde grandes conflitos aconteceram, instalou-se a agroindústria Reasa, reflorestadora da 
Amazônia S/A, que tinha como meta e plano desmatar, plantar e comercializar, mas que logo os planos mudaram e a empresa passou a se dedicar à produção do dendê.

Houve um grande problema e equívoco da Reasa, já que Jambuaçú era um grande território formado por mais de 15 comunidades remanescentes de quilombolas. Ali a resistência foi clara, real e o combate bélico existiu. A empresa queria plantar dendê, mas a concessão de terra incial, segundo os donos, não era suficiente para o projeto almejado.

A situação ficou mais difícil para a Reasa e outras firmas e empreendimentos que queriam mais terra a qualquer custo no município, quando no inicio da década de 1980, o Sindicato dos Trabalhadores Rurais- STR de Moju, fundado em 1973, passou, em 1984, para uma direção comprometida em fazer acompanhamentos nas comunidades que viviam situações como a de Jambuaçú. Também no final de 1970 havia chegado um padre da Itália com novas ideias, de acompanhar também e incentivá-las a lutar e resistir, ideais pautados na Teologia da Libertação, uma nova metodologia de fazer igreja na Amazônia.

À frente do Sindicato dos Trabalhadores Rurais estava Virgílio Serrão Sacramento e à frente da Igreja estava o Padre Sergio Tonetto. Ambos viajavam o município todo, iam ao encontro das Comunidades Eclesiais de Base, as chamadas e famosas CEBs dos anos de 1980. Onde houvesse um problema relacionado a conflitos pela posse da terra, eles estavam. Nos anos de 1980 foram um marco na luta pela resistência junto com outros nomes, como Aldenor dos Reis e Silva, Manoel Libório, Edgar Valente, Adalberto do Amaral, Manoel do Amaral, Armando Alves, Aventino Rodrigues, Maria do Livramento, Nazaré Valente e vários outros, a maioria do campo. Juntos fizeram muitos enfrentamentos.

No ano de 1984, a Reasa estava com o propósito de se apossar de uma grande quantidade de terras que ia desde a região do Jambuaçú até a fronteira da empresa produtora de coco, Sococo. Neste imbróglio, havia outra terra que estava em litigio com posseiros próximo da empresa de coco e com moradores das comunidades de Ipitinga e Curuperé. O negócio não estava fácil. O STR de Moju procurou fazer várias denúncias desse caso em Belém para as autoridades, como fizeram ao secretário e Segurança Pública, do então governador Jader Barbalho, mas nada, nenhuma providencia foi tomada. A situação ficou fora de controle. 
Um dos sócios da empresa Reasa, um sujeito que era da Bahia e havia sido eleito vereador nas eleições de 1982, havia tomado pra si a responsabilidade de 'abrir' caminho para demarcar a área que estava sendo grilada. Diante deste acontecimento, aconteceu em Moju uma das resistências mais expressivas da historia do município. Como as autoridades se omitiram tanto de Moju quanto de Belém, o conflito se tornou inevitável. No dia 07 de setembro de 1984, 44 trabalhadores das comunidades do Ipitinga e Curuperé se prepararam e se armaram com suas armas caseiras pra esperar o vereador e sócio da empresa que ia estar à noite fazendo a abertura do 'pico', área que demarcaria o então território da Reasa. No entanto, esta demarcação estaria passando por terras desses moradores, especialmente pelas terras do senhor Delorizano, que tinha documentos que comprovavam ser o legítimo proprietário desde o final do século XIX. Neste dia, aconteceu o desfecho seguinte:

A partir das $5 \mathrm{~h}$ da manhã os peões e o pessoal da firma começaram a chegar e às $6 \mathrm{~h} 30$ o trator começou a zoar e a trabalhar. Às $7 \mathrm{~h} 30$ apareceu o gerente, o Edmilson, e dois pistoleiros, conhecidos como Gordo e Mineiro, todos fortemente armados, com armas na mão direita e na esquerda munição. Quando saímos do mato, todos os grupos juntos a uma distância de 50 metros, os pistoleiros foram logo atirando, sendo correspondidos por nós. Sucederam-se vários tiros de ambas as partes. Em meio aos sucessivos tiros, nós corremos pela mata, sob tiros para o alto. Depois do tiroteio todos preocupados pensando se tinha acontecido alguma coisa com nosso companheiro. (SACRAMENTO, 2010, P. 23)

Este episódio ficou conhecido como "Os 44 do Ipitinga", como os jornais se referiram ao caso que foi significativamente noticiado. $\mathrm{O}$ vereador, um dos donos da empresa, acabou morto e os lavradores permaneceram nas duas comunidades até o dia 10 de setembro quando acabaram se entregando para a Policia e foram levados para cidade de Abaetetuba. Em uma das matérias do jornal $O$ Liberal foi destacado o seguinte titulo "44 posseiros presos como suspeitos: Moju". Grandes exageros foram descritos na matéria, dentre elas as de que os colonos estavam fortemente armados e embrenhados nas matas, de que precisou um grande contingente de soldados de outras localidades. Tudo desmentido posteriormente. Este caso acabou sendo encerrado sem ter nenhum culpado, uma vez que os lavradores se organizaram e decidiram falar uma única língua frente às autoridades, principalmente dos policiais. Ou seja, falariam tudo 
no plural, como falaram quando perguntados. Delegado: "Quem atirou”? "Quem estava armado"? E a resposta: "Nós"! (SACRAMENTO, 2009: P. 90).

Para este caso terminar com esse final, houve a importância significativa do STR de Moju, tendo a frente o líder sindical Virgílio Serrão Sacramento, bem como da igreja católica com o padre Sérgio Tonetto que acionaram outros movimentos sociais, advogados, sociedade civil para que interpelassem pelos lavradores presos, tendo surtido efeito, e a prisão sendo relaxada. Estes puderam viver em suas terras mais sossegados e sem serem incomodados por outros donos de projetos agroindustriais. A luta pela terra em Moju teve altos e baixo. Defesas de posseiros foram feitos pelos STR e pela igreja Católica. Vitórias foram conquistadas. Mas no bojo dos conflitos perdas também ocorreram.

Em 1987, por exemplo, quando o município ainda respirava grandes tensões no campo, uma baixa significativa: o líder sindical Virgílio Serrão Sacramento foi assassinado no dia 05 de abril. Virgílio já havia se destacado na luta em defesa pelos trabalhadores rurais de Moju, no inicio dos anos de 1980 ajudou a fundar o Partido dos Trabalhadores (PT) no estado do Pará, organizou a Central Única dos Trabalhadores (CUT) da região Guajarina, com sede no município de Abaetetuba, havia sido eleito membro diretor da Federação dos Trabalhadores na Agricultura do Estado do Pará (FETAGRI-PA), entidade que havia sido 'tomado' das chamadas mãos dos pelegos em fins do mês de março deste ano.

A morte do líder sindical Virgílio Serrão Sacramento foi um marco na derrota dos movimentos sociais, principalmente nos municípios da região Guajarina. Havia apenas o caso do também líder sindical Benedito Alves Bandeira, o Benezinho que havia sido assassinado no município de Tomé-Açú no ano de 1984 e houve grande repercussão de sua morte naquele ano. Os pistoleiros confessos do crime, presos pela policia local, ao serem levados para a delegacia, foram arrancados pela população um a um e mortos, trucidados, todos linchados, e queimados, numa ação bárbara.

Virgílio que era casado com Maria do Livramento Diniz Sacramento, deixou a viúva e onze filhos pra criar. Eram estes, José Dorival Diniz Sacramento, Maria do Livramento Diniz Sacramento, Edna do Socorro Diniz Sacramento, Sandra Regina Diniz Sacramento, Elias Diniz Sacramento, Joao Agnelo Diniz Sacramento, Maria de Lourdes Diniz Sacramento, Marlene Diniz Sacramento, Ilene Diniz Sacramento, 
Virgílio Diniz Sacramento Júnior e Noemi Diniz Sacramento. Fora Dorival e Dinalva, os demais eram menores de idade. Além da esposa e dos onze filhos órfãos, os lavradores do município também se sentiram dessa forma, sem a liderança principal. (SACRAMENTO, 2012).

A morte do sindicalista nunca foi esclarecida. Seu assassinato se deu em forma de atropelamento, quando voltava da cidade para sua casa que ficava a oito quilômetros da sede do município. Ele voltava em sua moto, uma modelo C100, estilo mobilete, quando a um quilometro foi tomado por trás pelo caminhão pertencente a uma serraria do município de Tailândia. O impacto da batida foi muito forte que o líder sindical foi arremessado a mais de cem metros, tendo o motorista a frieza de frear e depois passar por cima de seu corpo, causando morte instantânea.

O homicídio culposo foi detectado no dia crime pelo delegado de policia, que não hesitou em afirmar que era uma morte proposital, uma vez que era um dia de domingo à tarde, quando não havia movimento na rodovia e o motorista tinha todas as condições de fazer a ultrapassagem sem ter causado o acidente fatal. Embora tenha sido preso alguns dias depois, o motorista assassino nada falou perante as autoridades policiais, seus advogados conseguiram pagar fiança, ele respondeu o processo em liberdade. Julgado anos mais tarde, sua condenação foi em regime aberto e representou um prêmio à impunidade.

Em 1988, os conflitos ainda continuavam em alta em Moju. Desta vez a situação voltava-se novamente para a região do Jambuaçú. As terras quilombolas continuavam sendo ameaçadas de serem tomadas por latifundiários, velhos e novos. Em janeiro de deste ano, foram mortos dois homens dessa região. Quando estavam bebendo na cidade, um homem conhecido apenas pelo prenome de 'Canindé e o outro Joao anunciaram que iriam 'resolver' o problema do município, que iriam matar o pistoleiro mais temido, chamado de Claudomiro e um cabo da policia conhecido por 'Pezão'. Foram denunciados à policia por ameaças e baderna. Depois de presos, na calada da noite desse mesmo dia, foram subtraídos da delegacia e levados a um local ermo, onde primeiro foram obrigados a cavar suas sepulturas, para em seguida passarem por processos de torturas, pois tiveram suas orelhas cortadas, seus braços decepados, para finalmente serem mortos com tiros. 
A morte dos dois homens, quase sem nome e sem rostos praticamente, aqueceu os ânimos das comunidades da região do Jambuaçú. Seus moradores já prevendo o que poderia ter acontecido com os dois tomaram uma decisão: invadir a sede do município. Nestes tempos, a cidade convivia com vários pistoleiros que andavam tranquilamente pela cidade. $\mathrm{O}$ chefe do grupo era o então Claudomiro, que tinha a conivência da policia local. Claudomiro não era um pistoleiro comum, suas características eram de um homem comum, da sociedade. Fazia festas e sempre estava junto com pessoas importantes e influentes, como prefeito, alguns vereadores, não despertava suspeitas. Assim, ninguém podia mencionar seu nome em relação aos conflitos.

No entanto, os moradores das comunidades de Jambuaçú e de outras partes do município mojuense tinham plena convicção de que Claudomiro era o líder dos pistoleiros. Era ele quem recebia as 'encomendas' pra se limpar uma determinada área. Assim, sem terem duvidas disso, os moradores das comunidades quilombolas prepararam a ação. No dia 08 de janeiro, de manha bem cedo, depois de terem percorrido vários quilômetros até a sede do município, principalmente a noite, para não serem vistos, um grupo de aproximadamente 78 homens chegaram próximo da sede. Antes de o dia clarear, pintaram seus rostos de carvão para não serem reconhecidos por ninguém, a um quilometro da sede, marcharam, todos juntos, como um exercito, com suar armas em punho, as armas de caça, espingardas, de todos os calibres, 28, 32, 36, 44. Enfim, foram em rumo à direção da batalha, pra tentar por fim a uma guerra que estava ocorrendo desde os fins dos anos de 1970 (SACRAMENTO, 2012).

Na sede do município, como ainda era de manhã neste dia 08 , a cidade ainda dormia. Quando os primeiros moradores, acordando ainda e que estavam nas ruas viram a ação de um grande numero de homens pintados entrando nas ruas, recolheram-se para suas casas novamente. Chamados de revoltosos pela imprensa posteriormente, este homens tinham suas ações organizadas. Quando chegaram no centro da cidade, dividiram-se em dois grupos. O primeiro foi para um comercio 'pegar' frascos', vasilhames para em seguida irem para o posto de gasolina onde também 'pegaram' o quanto puderam combustível. O segundo grupo rumou para o único posto telefônico existente em Moju. Ali, com tiros, destruíram todos os equipamentos, ficando o posto incomunicável. Em seguida os dois grupos se encontraram e foram em direção a casa do Claudomiro. Chegando lá, este já havia sido avisado e fugido do local. Os 'revoltosos' 
então tocaram fogo na casa. Em seguida foram pra delegacia de policia pegar o 'Pezão' e o comissário de Polícia, que era o responsável na época pela 'segurança'. Nem 'Pezão', nem o comissário se encontravam mais no local, como Claudomiro, também haviam fugido. Atearam fogo também, mas diferente da casa do pistoleiro que ardeu em chamas, a delegacia queimou apenas parte.

Findo esta ação, os 'revoltosos' tomaram o caminho de volta. Soube-se posterior que Claudomiro havia fugido em seu fusca. Que Pezão, às pressas havia tomado o caminho do porto da balsa para ir pra Abaetetuba e que o comissário de policia havia se escondido em um tonel de óleo queimado no posto da Celpa que ficava próximo da delegacia de policia do município. Horas depois, no mesmo dia do ato, a cidade foi tomada por soldados militares de outros municípios como Abaetetuba, Barcarena e Belém. Nos dia 09, as pessoas só comentavam isso, ainda mais por conta da cobertura nos meios de comunicação como nos jornais A Província do Pará e O Liberal. Contra os 'revoltos' da região do Jambuaçú, não houve a abertura de um processo, pois não sabiam quem eram os envolvidos. Assim como vieram, voltaram. O município respirou por um período uma leve paz, uma pequena tranquilidade, uma vez que Claudomiro, tão cedo não voltaria pra lá e os demais pistoleiros seguiram uns tempos sumidos.

A década de 1980 em Moju foi muito tensa, foi a década de grandes transformações, da chegada dos grandes projetos agroindustriais que há séculos respirava uma vida tranquila, fosse na área urbana, fosse na zona rural. Com a chegada do agronegócio, tudo mudou. O ideal dos militares era de modificar a Amazônia como um todo, e obviamente o Moju estava nesse meio. O que os militares não contavam era com a organização dos moradores desses espaços, principalmente dos colonos, lavradores, quilombolas, indígenas. Essas organizações foram de fundamental importância para que tudo não saísse como planejado pelos donos dos grandes projetos. $\mathrm{O}$ que se viu então em vários momentos foi à resistência frente a esses ideais. Nesse embate todo, perdas foram sentidas, ora de um lado, ora de outro. Para os trabalhadores rurais, as perdas foram muito sentidas, mas todas elas tiveram e tem um sentido, a permanência na terra pelos os que ficaram. Pra memoria de todos, principalmente dos que se foram na luta nesses idos anos de 1980, na Amazônia, no Pará e no município de Moju resta o trabalho de algum pesquisador, interessado em dar vida a essas histórias, 
as histórias de lutas e resistências traduzidas em literaturas, para que outras gerações não esqueçam, para que nunca mais aconteça novamente.

\section{Conclusão}

Pensar a história de resistências na Amazônia, depois do golpe dos militares não é tarefa fácil, nem será tão cedo. Há muitos silêncios que precisam ser vencidos. Os traumas deixados na memória de populações das mais diversas partes da região amazônica são infindáveis. Se pensarmos a dimensão desta região e suas populações vitimas do período ditatorial, termos muito trabalho a fazer. Quantas comunidades indígenas foram vitimas dos projetos dos grandes projetos para a região? Não se sabe ao certo, nem tampouco se saberá, mas o certo é que na memoria dessas populações as lembranças são muito dolorosas.

Por outro lado, centenas de famílias que viviam na região conhecida como Bico do Papagaio, onde ocorreu a suposta "Guerrilha do Araguaia", por exemplo, e foram vítimas das atrocidades cometidas pelas tropas militares que ali montaram bases para fazer operações e consequentemente prender os tais guerrilheiros. Embora já se tenham produzidos trabalhos sobre o tema, há ainda um grande número de famílias que residem nos municípios próximos como São Geraldo do Araguaia e São Domingos do Araguaia e que ainda precisam ser lembrados pra contarem suas versões dos faltos que marcaram aquele período tenebroso da história recente daquela parte da Amazônia.

Há ainda o silencio letal por parte dos militares que após o fim do regime militar criaram um pacto do silencio pra nada falarem sobre o tema. Obviamente que a questão é mais complexa, uma vez que por trás desses homens, muitos segredos estão escondidos, seja das torturas que praticaram, seja de possíveis assassinatos de homens e mulheres que ainda hoje são tidos como desaparecidos. É algo que intriga a sociedade como um todo e martiriza muitas famílias, principalmente daquelas que tiveram alguém envolvido na guerrilha do Araguaia.

A diversidade de trabalhos já produzidos e publicados soa como alento, uma vez que aos poucos vozes vão ecoando e falando, gritando sobre esse tempo difícil que foi a presença dos militares no poder. Esses trabalhos representam parte significativa de populações que resistiram e que ao fazerem essas resistências em forma de luta, guardam em suas memórias histórias interessantes, mostrando que nem sempre quem 
vence é o mais forte, mas aquele que em muitas vezes consegue se organizar em grupos e ao lutarem coletivamente, seus objetivos são alcançados. A história da luta e resistência na Amazônia em tempos recentes não serve apenas para retratar essas memórias, ou simplesmente para ser traduzidas em textos literários, na literatura de resistência, mas acima de tudo para servir de exemplo para gerações futuras, para que se lembrem sempre, para que nunca mais aconteça.

\section{Referências}

ACEVEDO MARIN, Rosa Elizabeth \& CASTRO, Edna Maria Ramos de. Negros do Trombetas: guardiães de matas e rios. $2^{\mathrm{a}}$ ed. Belém: Cejup, 1998.

BACELLAR, Carlos. Fontes documentais: uso e mau uso dos arquivos. In: PINSKY, Carla Bassanezi. (Organizadora). Fontes históricas. 2a . Ed.. São Paulo: Contexto, 2010.

BATISTA, Regina Célia Corrêa. Dinâmica Populacional e Atividade Madeireira em uma Vila da Amazônia: a Vila de Moju (1730-1778). Dissertação de mestrado. Belém: PPHIST/UFPA, 2013.

BRELAZ, Walmir Moura. Os sobreviventes do massacre de Eldorado do Carajás: um caso de violação do principio da dignidade da pessoa humana. Belém: [s/n], 2006.

CARNEIRO, Ana; CIOCCARI, Marta. Retrato da Repressão Política no Campo Brasil 1962-1985 - Camponeses torturados, mortos e desaparecidos. - Brasília: MDA, 2011.

FONTES, Edilza. O peão de trecho e o peão de casa: identidade operária entre os trabalhadores da construção civil de Barcarena no canteiro de obras da ALBRAS/ALUNORTE. Belém: Novos Cadernos NAEA v. 6, n. 1. 2003.

FERREIRA, Jorge; GOMES, Ângela de Castro. 1964: o golpe que derrubou um presidente, pôs fim ao regime democrático e instituiu a ditadura no Brasil. $1^{\mathrm{a}}$ Ed. - Rio de Janeiro: Civilização Brasileira, 2014.

FERREIRA, Vandilson Gomes \& MARTINS. Simone Cristina Menezes. Produção literária mojuense. Trabalho de Conclusão de Curso de Letras. Moju: UEPA, 2016. (Não publicado)

FIGUEIRA, Ricardo Rezende. Rio Maria: Canto da Terra. $1^{a}$ Ed. Petrópolis: Vozes, 1993.

FONTES, Edilza. O dever da memória e a documentação sobre a Ditadura CivilMilitar na Universidade Federal do Pará. Acervo, Rio de Janeiro, v. 27, no 1. Janeiro/julho, 2014. 
FRANCO, Renato. Literatura e Catástrofe no Brasil: anos 70. In: SELGMANNSILVA Márcio. História, memoria e literatura: o testemunho na era das catástrofes. Campinas, SP: Editora da Unicamp, 2003.

LOUREIRO, Violeta Refkalefsky. Estado, bandidos e heróis: utopia e luta na Amazônia. Belém: Cejup, 1996.

MAIA, Maria Lúcia Sá \& MOURA, Edila A. Ferreira. Da farinha ao alumínio: os caminhos da modernização na Amazônia. In: CASTRO, Edina, MOURA, Edila A.F. e MAIA, Maria Lúcia Sá (orgs.). Industrialização e grandes projetos: desorganização e reorganização do espaço. Belém: Editora da UFPA, 1995.

MORAES, Mário Sérgio de. 50 anos construindo a democracia: do golpe de 64 a Comissão Nacional da Verdade. São Paulo: Instituto Vladimir Herzog, 2014.

OLIVEIRA, Walter Pinto. 1932 - A Revolução Constitucionalista no Baixo Amazonas: contexto, revolta e produção do silencio”. Belém: Editora Paka-Tatu, 2013.

PETIT, Pere. Chão de promessas: elites políticas e transformações econômicas no estado do Pará pós-1964. Belém: Paka-Tatu, 2003.

PETIT, Pere \& CUÉLLAR, Jaime. O golpe de 1964 e a instauração da ditadura civil-militar no Pará: apoios e resistências. Estud. hist. (Rio J.) vol.25 nº 49 Rio de Janeiro Jan./June 2012.

REIS, Daniel Aarão. Ditadura e democracia no Brasil: do golpe de 1964 à Constituição de 1988. 1ed. - Rio de Janeiro: Zahar, 2014.

SCHMINK \& WOOD, Marianne \& Charles H. Conflitos sociais e a formação da Amazônia [tradução de Noemi Myiasaka Porro e Raimundo Moura]. Belém: Ed. UFPA, 2012.

RICCI, Magda. Um morto, muitas mortes: a imolação de Lobo de Souza e as narrativas da eclosão cabana. In: Faces da história da Amazônia. Belém: Editora Paka Tatu, 2006.

SARGES, Maria de Nazaré. Belém: riquezas produzindo a Belle-Époque (1870-1912). $3^{a}$ ed. Belém: Editora Paka-Tatu, 2010.

SACRAMENTO, Edna do Socorro Diniz. A luta pela terra em Moju: a história do sindicalista Virgílio Serrão /sacramento. Monografia de Ciências Sociais. UFPA Campus de Abaetetuba, 2000.

SACRAMENTO, Elias Diniz. A luta pela terra numa parte da Amazônia: o trágico 07 de setembro em Moju e seus desdobramentos. Belém: Editora Açaí, 2009.

SACRAMENTO, Elias Diniz. As almas da terra: a violência no campo mojuense. Belém: Editora Açaí, 2012. 